\title{
Performance of Dolomite Calcination in a Bench-Scale Rotary Kiln
}

\author{
Winny Wulandari ${ }^{*},{ }^{1}$, Subagjo ${ }^{1}$, Anggoro Tri Mursito ${ }^{2}$, Fadly Junico Juanjaya ${ }^{1}$, and Muhammad Faqih Alwi ${ }^{1}$ \\ ${ }^{1}$ Department of Chemical Engineering, Faculty of Industrial Technology, Institut Teknologi Bandung, Jalan Ganesa No.10 Bandung \\ 40132, Indonesia \\ ${ }^{2}$ Research Centre for Geotechnology, Indonesia Institute of Sciences (LIPI), Jl. Cisitu Bandung 40135, Indonesia
}

\begin{abstract}
Dolomite calcination is one of process steps to prepare calcined dolomite for raw materials in magnesium production. Calcination of dolomite involves heating the raw material at sufficient temperature in order to release the carbon dioxide from its carbonate minerals. This process is commonly conducted in a rotary kiln. There have been a number of calcination studies in a laboratory scale, but the study of dolomite calcination in a larger scale is very scarce. This research is aimed to study the performance of dolomite calcination in a bench-scale rotary kiln with 500 gram of feed. The effect of various parameters, including temperatures, feed rate, rotating frequency, and particle size were examined. The temperature of rotary kiln was varied between 700 and $1000^{\circ} \mathrm{C}$, while the particle size of dolomite was varied between $0.149-$ $0.297 \mathrm{~mm}$ and up to $10-15 \mathrm{~mm}$. The temperature distribution inside the rotary kiln was also measured. It is obtained that a conversion of $92 \%$ was attained at operation temperature of $1000^{\circ} \mathrm{C}$, which is at a higher temperature compared to the laboratory scale, where a conversion of $100 \%$ was obtained at $900^{\circ} \mathrm{C}$. This imply that the effect of heat transfer also plays important role in the calcination of dolomite especially at a larger scale.
\end{abstract}

\section{Introduction}

Dolomite, $\mathrm{CaCO}_{3} \cdot \mathrm{MgCO}_{3}$, is a mineral found in several places in Indonesia with an estimated reserve of 2,396,707 thousand tons, based on the data from the Ministry of Energy and Mineral Resources in 2010. Dolomites which are found in Gresik are relatively pure, which contains $40-45 \%$ of $\mathrm{MgCO}_{3}$ and $55 \%$ of $\mathrm{CaCO}_{3}$, with some impurities include $\mathrm{SiO}_{2}(0,2 \%), \quad \mathrm{Fe}_{2} \mathrm{O}_{3}$ $(0,65 \%)$, and $\mathrm{Al}_{2} \mathrm{O}_{3}(0,03 \%)$.

Dolomite calcination is an important step in the processing of dolomites into other materials of higher value such as fluxes and additives in steel processing smelters, kieserite $\left(\mathrm{MgSO}_{4} \cdot \mathrm{H}_{2} \mathrm{O}\right)$ fertilizer, refractory bricks, sulfur dioxide capture medium in Flue Gas Desulfurization (FGD), and as the raw materials for magnesium production.

According to Samtani et al [1], dolomite begins to decompose into its oxide in one step in an inert atmosphere, as in the following reaction:

$$
\mathrm{CaMg}\left(\mathrm{CO}_{3}\right)_{2(\mathrm{~s})} \rightarrow \mathrm{CaO} \cdot \mathrm{MgO}_{(\mathrm{s})}+2 \mathrm{CO}_{2(\mathrm{~g})}
$$

The mechanism is different when dolomite decomposes in atmosphere containing $\mathrm{CO}_{2}$, as it decomposes with two step reactions as in the following:

$$
\begin{gathered}
\mathrm{CaMg}\left(\mathrm{CO}_{3}\right)_{2(\mathrm{~s})} \rightarrow \mathrm{CaCO}_{3(\mathrm{~s})}+\mathrm{MgO}_{(\mathrm{s})}+\mathrm{CO}_{2(\mathrm{~g})} \\
\mathrm{CaCO}_{3(\mathrm{~s})} \rightarrow \mathrm{CaO}_{(\mathrm{s})}+\mathrm{CO}_{2(\mathrm{~g})}
\end{gathered}
$$

The study on dolomite decomposition in a TGA using nitrogen as the inert atmosphere by the authors [2] showed that decomposition of dolomite is a one step process that began at $700^{\circ} \mathrm{C}$ and finished at $850{ }^{\circ} \mathrm{C}$ with activation energy of $149,5 \mathrm{~kJ} / \mathrm{mol}$. This study also showed that the maximum conversion of dolomite calcination in a laboratory scale tubular furnace is $100 \%$ at $900{ }^{\circ} \mathrm{C}$. Meanwhile, study on dolomite decomposition in tubular furnace using atmosphere consisting of air and $\mathrm{CO}_{2}$, as an atmospheric replication in rotary kiln, shows that decomposition of dolomite occurs in two steps, starting at $650^{\circ} \mathrm{C}$ until $820^{\circ} \mathrm{C}$ with $162 \mathrm{~kJ} / \mathrm{mol}$ of activation energy [3]. In addition, the maximum conversion of $80-90 \%$ in this atmosphere was achieved at $900{ }^{\circ} \mathrm{C}$.

Even though the laboratory scale study shows that the conversion of dolomite decomposition reaching $99 \%$ at $900{ }^{\circ} \mathrm{C}$, the rotary kiln in commercial scale operates at $1100{ }^{\circ} \mathrm{C}$ to $1200{ }^{\circ} \mathrm{C}$, which means there is unnecessary energy losses. Often the rotary kiln is equipped with preheater to preheat the feed prior to the rotary kiln using the flue gas from combusted gas in the rotary kiln, and cooler to reduce the temperature of calcined materials. Only few literatures that shows the knowledge of rotary kiln process in the scale that larger than laboratory scale. The discrepancy in literature between bench-scale data and full-scale data is the motivation behind this research.

This research aims to understand the effect of temperature, atmospheric condition during reaction, 
particle size of dolomites, and rotating frequency of rotary kiln on dolomite conversion and distribution of residence time and temperature in rotary kiln.

\section{Methodology}

The experiment on calcination was carried out in four steps: sample preparation, determination of initial mass and composition of the sample, calcination, and determination of final mass and composition of the sample. It was carried out in rotary kiln at the specified temperature. Figure 1 shows the photograph of the bench scale rotary kiln. Several variables were varied in order to get rotary kiln performance data on dolomite calcination. The remaining sample at the end of calcination was weighed and analyzed to determine the conversion of dolomite. A final analysis was also performed to determine the final composition of the sample. Residence Time Distribution (RTD) of dolomite was determined by retaining samples exiting the rotary kiln over a certain interval. Actual temperature distribution inside the rotary kiln was determined by real time measurement using a thermocouple.

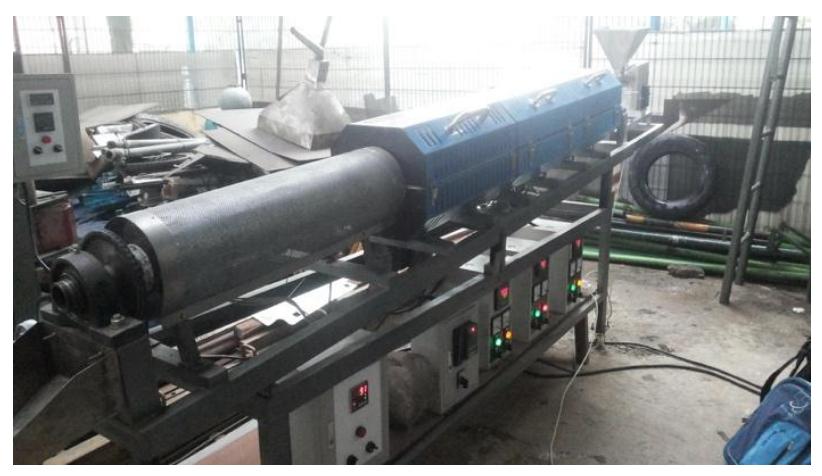

Fig. 1. Bench-scale rotary kiln

\subsection{Procedures}

\subsubsection{Sample Preparation}

Four categories of dolomite particle size were used: $0.149-0.297 \mathrm{~mm} ; 1.19 \mathrm{~mm}-2.83 \mathrm{~mm} ; 2.83-6.73$ $\mathrm{mm}$; and $10-15 \mathrm{~mm}$. Dolomites were crushed using jaw crusher and ball mill, then separated using mechanical sieve to obtain the desired particle size. As much as 500 $\mathrm{g}$ of sample was used for the next step.

\subsubsection{Initial Composition Determination}

Composition analysis was carried out qualitatively using X-Ray Diffraction (XRD). The output given by XRD were in the form of crystal structure data and constituents of dolomite. Dolomite sample were also analyzed using TG (thermogravimetry) to determine the mass reduction when heated to $950^{\circ} \mathrm{C}$.

\subsubsection{Measurement of Residence Time Distribution}

The prepared sample with mass of 500 grams was fed into the rotary kiln. The sample exiting the kiln every 2 minutes were collected and weighed. The average residence time of the sample can be inferred from the residence time distribution.

\subsubsection{Calcination}

The kiln temperature is set to be constant at the specified temperature for each variation: $700^{\circ} \mathrm{C}, 800^{\circ} \mathrm{C}, 900^{\circ} \mathrm{C}$, and $1000^{\circ} \mathrm{C}$. The sample is then fed into the rotary kiln. The experiment is carried out in atmosphere consisting of ambient air and carbon dioxide $\left(\mathrm{CO}_{2}\right) . \mathrm{CO}_{2}$ is fed into the kiln using a hose. The flow rate of $\mathrm{CO}_{2}$ is set at 7 $\mathrm{L} /$ minute. The flow is measured using a flowmeter. Rotary kiln rotation frequency is also varied at 18.25; 29.75; 40.87; and $52.10 \mathrm{rpm}$. Calcined sample exiting the kiln was collected in a container and then weighed to determine the conversion of dolomite calcination.

The conversion of dolomite calcination is calculated by the amount of carbon dioxide that is released from the feed, which is assumed from the weight of initial feed subtracted by the weight of final sample.

\subsubsection{Actual Temperature Distribution in Rotary kiln}

The actual temperature distribution inside the rotary kiln is measured directly using thermocouple. Temperature measurement was carried out axially and radically. Axial temperature measurement is carried out every $10 \mathrm{~cm}$ until $60 \mathrm{~cm}$ from the edge of the rotary kiln. Radial temperature measurement was carried out in two points, in the center of the rotary section and $2 \mathrm{~cm}$ from the middle.

\section{Results and Discussions}

\subsection{Analysis of the Feed}

Figure 2 shows the X-ray diffraction analysis of dolomite. Dolomite contains mineral dolomite $\left(\mathrm{CaCO}_{3} \cdot \mathrm{MgCO}_{3}\right)$, calcite $\left(\mathrm{CaCO}_{3}\right)$, with impurities such as hematite $\left(\mathrm{Fe}_{2} \mathrm{O}_{3}\right)$ and feldspar (silica minerals).

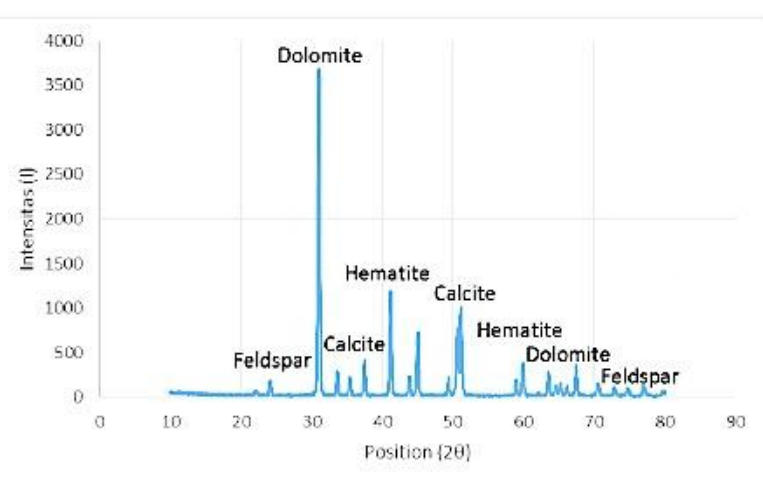


Fig. 2. XRD Analysis of Dolomite

The thermogravimetric analysis has been carried in the previous study by the authors [2] and shown in Figure 3.

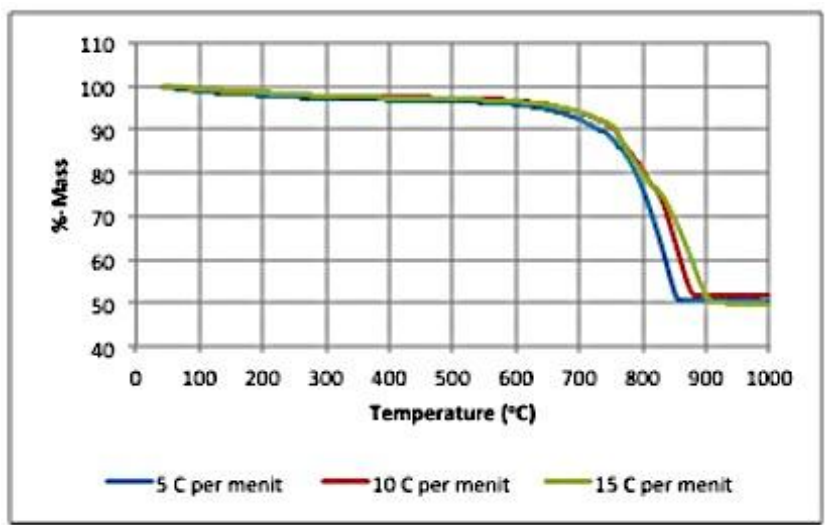

Fig. 3. TGA of Dolomite [2]

Dolomite in inert atmosphere started to decompose at temperature of $600{ }^{\circ} \mathrm{C}$ and finished the decomposition at temperature lower than $900{ }^{\circ} \mathrm{C}$. The total mass loss of dolomite is approximately $50 \%$, which take accounts for the mass of carbon dioxide that is released from this carbonate minerals. For this reason, the variation of temperature in the bench experiments is from 700 to 900 ${ }^{\circ} \mathrm{C}$.

\subsection{Effect of Temperature}

The effect of temperature on the conversion of dolomite calcination at various particle sizes is shown in Figure 4. The rotation frequency used in the experiment is 29.75 rpm with the inclination of $3^{\circ}$. The calcination experiments were conducted using various particle sizes of feed material.

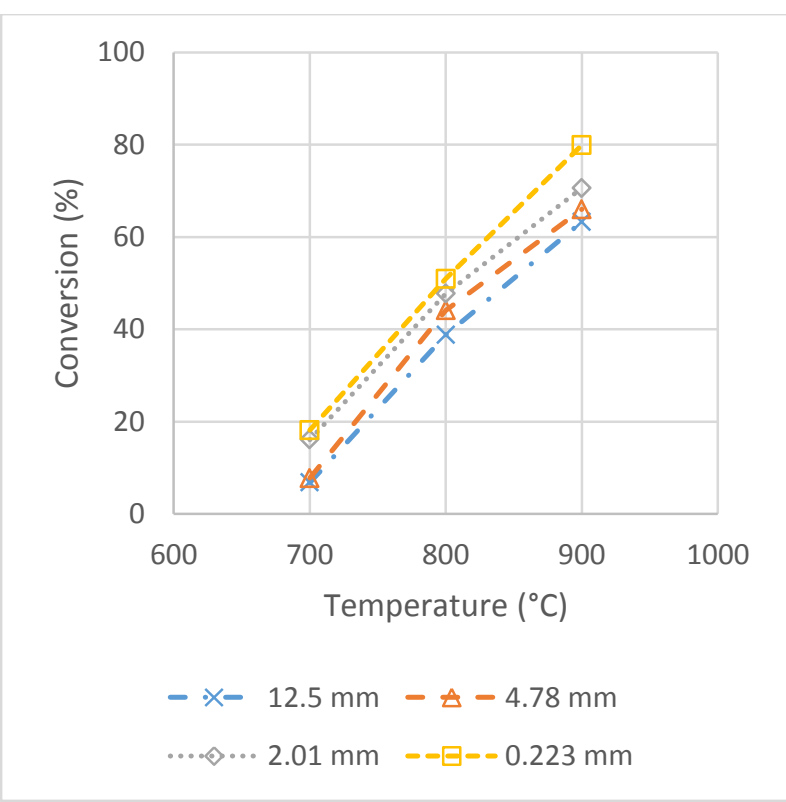

Fig. 4. Effect of temperature on calcination

Based on Figure 4, the conversion of dolomite calcination is ranging from 6 to $19 \%$ at $700{ }^{\circ} \mathrm{C}$. The recovery increases to $62-80 \%$ at $900{ }^{\circ} \mathrm{C}$. Compared to the laboratory scale, the recovery at $700{ }^{\circ} \mathrm{C}$ is much lower, only $20 \%$. This may be caused by the materials is still in the heating zone, as the feed material enter the rotary kiln in a room temperature. Thus, at the rotary kiln temperature of $700{ }^{\circ} \mathrm{C}$, the part of rotary kiln only heating the feed and when calcination begin to occur, the feed material has started to enter the outlet of the rotary kiln.

At a higher temperature, for example at $900{ }^{\circ} \mathrm{C}$, the preheating of material feed occur faster, thus the calcination recovery is higher. The higher the reaction temperature of calcination, the higher the conversion of the reaction. The primary cause is more reactants has gained enough activation energy from higher operating temperature to allow it to undergo calcination. The reaction rate also increases with increasing temperature thus making the resulting calcination conversion higher. Temperature has the most significant effect compared to other process variables.

The effect of temperature on conversion of the reaction is studied further at $1000^{\circ} \mathrm{C}$ using sample with particle size of $1.19-2.83 \mathrm{~mm}$. Figure 2 shows the change in conversion when temperature is set up to $1000^{\circ} \mathrm{C}$.

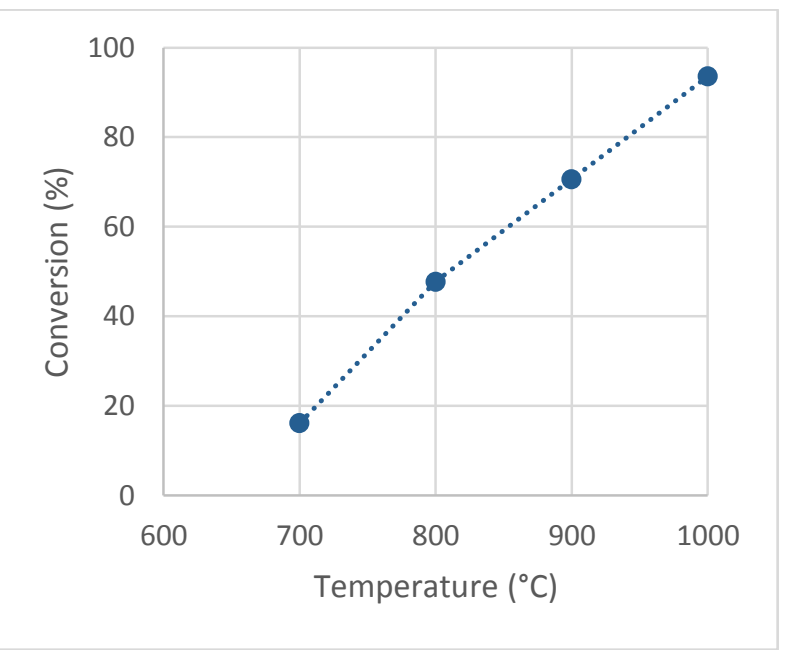

Fig. 5. Calcination conversion at $1000^{\circ} \mathrm{C}$

Figure 5 shows that higher temperature up to $1000^{\circ} \mathrm{C}$ results in higher conversion. Compared to laboratory scale, the conversion of dolomite calcination at bench scale is obtained at higher temperature. For example, using inert gas, dolomite calcination conversion is $100 \%$ at 900 and by using $\mathrm{CO}_{2}$ containing atmosphere, the conversion is $80-90 \%$ at $900{ }^{\circ} \mathrm{C}$, while the calcination conversion at bench scale at $900{ }^{\circ} \mathrm{C}$ is 72 $\%$. This discrepancy shows clearly that at bench scale, with larger capacity, will result in less recovery. The possibility of the cause may be from the heat transfer of the heat source to the center of particles, mass transfer, etc. This should be studied further. 


\subsection{Effect of Particle Size}

The effect of dolomite particle size on reaction conversion is shown in Figure 6. The experiments were performed at rotation frequency of $29.75 \mathrm{rpm}, 3^{\circ}$ in inclination, and atmosphere consisting of air at $700^{\circ} \mathrm{C}$, $800^{\circ} \mathrm{C}$, and $900^{\circ} \mathrm{C}$.

It can be seen that as the particle size decreases, the resulting conversion increases. This is in accordance with the theory that the diminution of particle size in the same mass causes the overall surface area of the particle to be larger. As the surface area of the particle increases, the incoming heat rate increases, thus with the same residence time, the greater the incoming heat. As the heat increases, more particles reach the activation energy need for calcination and are converted to calcium and magnesium oxide.

Particle size affects conversion less significantly compared to temperature because the heat transfer is due to heat transfer into dolomite particles is well under way. Rotary kiln rotation helps distribute the incoming heat to all the particles inside the kiln.

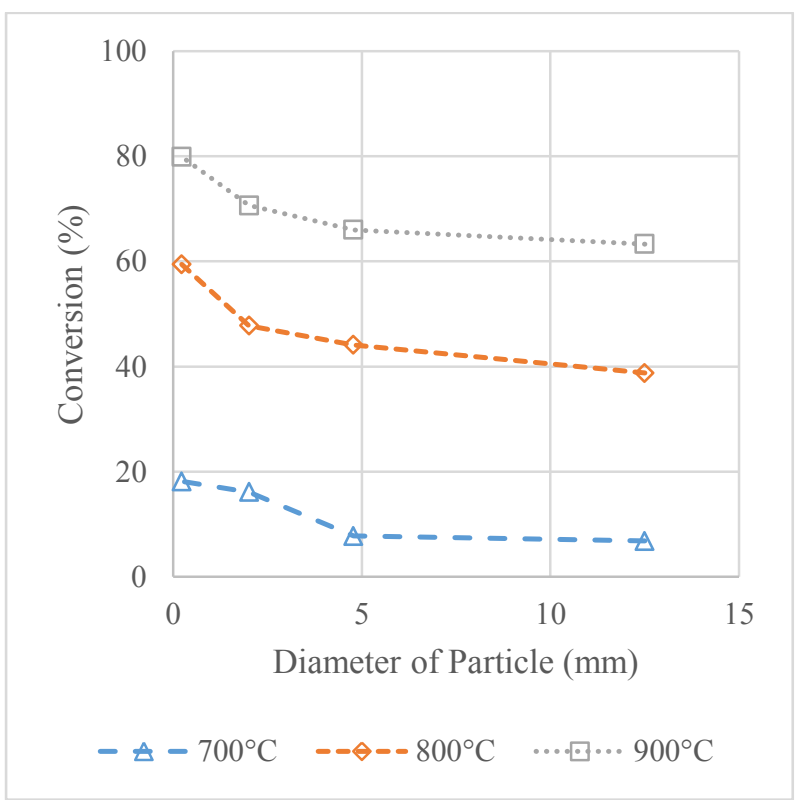

Fig. 6. Effect of particle size on calcination

\subsection{Effect of Residence Time Distribution (RTD)}

Dolomite sample RTD inside the kiln with a total mass of 500 grams is shown in Figure 7.

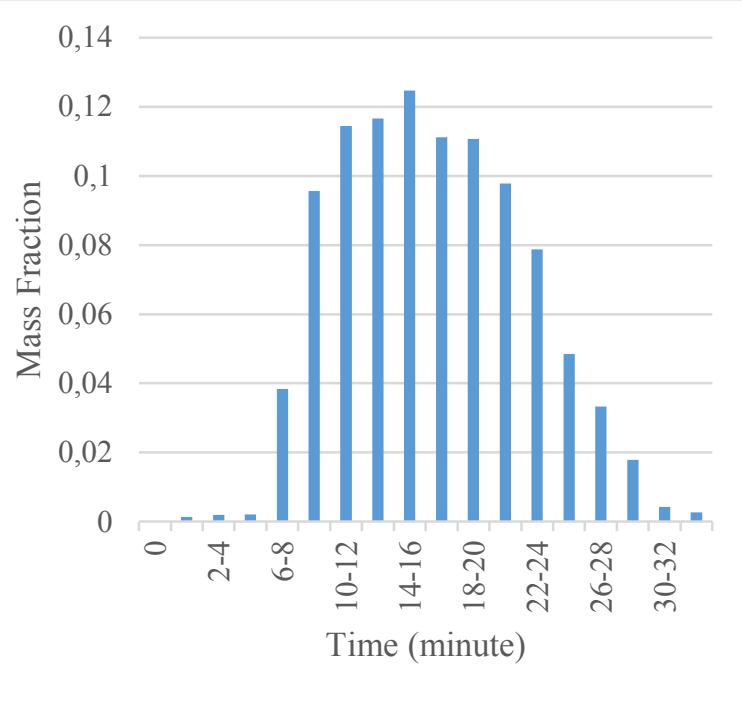

Fig. 7. Dolomite RTD inside the kiln

It can be inferred from Figure 4 that dolomite particles generally have a residence time $8-30$ minutes. The average residence time obtained from the RTD is 17.5 minutes. The RTD pattern resembles normal distribution (Gaussian distribution). Average mass rate of dolomite is $28.4 \mathrm{grams} / \mathrm{min}$ based on the residence time.

\subsection{Temperature Distribution profile}

Temperature distribution measurements were carried out at three different temperature settings: $700^{\circ} \mathrm{C}, 800^{\circ} \mathrm{C}$, and $900^{\circ} \mathrm{C}$. Figure 8 and 9 shows the temperature distribution measurements at the center of rotary kiln $(\mathrm{r}$ $=0 \mathrm{~cm}$ ) and at a radial distance of $2 \mathrm{~cm}$ from the center of the rotary kiln $(\mathrm{r}=2 \mathrm{~cm})$.

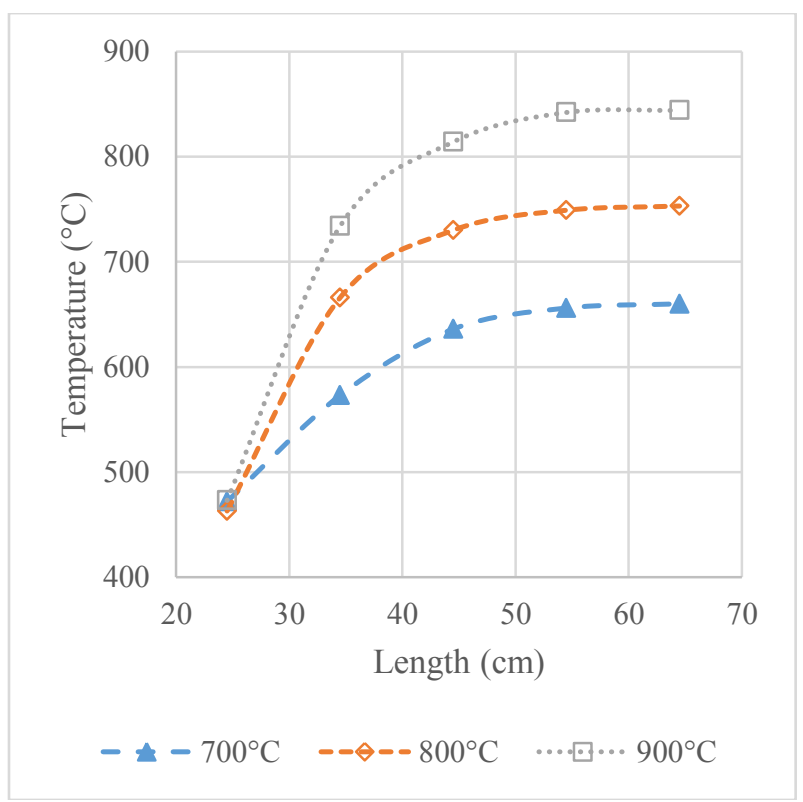

Fig. 8. Temperature distribution at the center of the kiln 


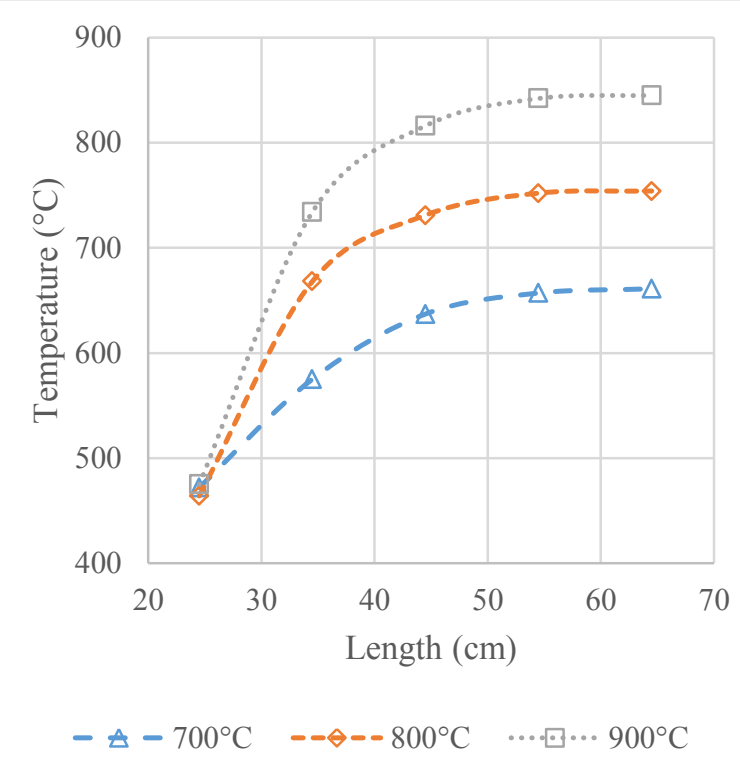

Fig. 9. Temperature distribution $2 \mathrm{~cm}$ from the center of the kiln

At the same radial length, the temperature increases over the axial length. At greater axial length, the thermocouple is placed further from the entry point which is at ambient temperature, thus making the temperature higher. At $50 \mathrm{~cm}$ from entry point, the temperature is starting to become constant, thus further measurement is unnecessary.

The radial temperature distribution is relatively unchanged compared to the axial temperature distribution. This is due to the small kiln diameter compared to the length of the kiln. The largest radial temperature difference is only $2^{\circ} \mathrm{C}$.

According to the actual temperature distribution from Figure 5 and Figure 6, there is a temperature difference from the set point (roughly $50^{\circ} \mathrm{C}$ ). This explains the phenomenon when the temperature set point is increased to $1000^{\circ} \mathrm{C}$, the calcination conversion still increases up to $90 \%$ which is supposed to be achieved at roughly $950^{\circ} \mathrm{C}$ and should not go any higher according to the TG analysis.

\section{Summary}

The study of dolomite calcination at bench scale has been carried out. The effect of various parameters, including temperatures, feed rate, rotating frequency, and particle size were examined. The temperature of rotary kiln was varied between 700 and $1000{ }^{\circ} \mathrm{C}$, while the particle size of dolomite was varied between $0.149-$ $0.297 \mathrm{~mm}$ and up to $10-15 \mathrm{~mm}$. The temperature distribution inside the rotary kiln was also measured. The experiments at bench scale enable us to obtain data that is differ from the data at the laboratory scale, and may act as a bridge to understand the phenomena of dolomite calcination at the commercial scale. Of many variables that has been examined, the conversion of dolomite calcination at bench scale reaches $72 \%$ at 900 ${ }^{\circ} \mathrm{C}$ and $93 \%$ at $1000 \mathrm{C}$. The lower conversion of dolomite calcination is postulated to be caused by larger capacity, with affect the heat transfer from the heat source to dolomite particles. Further research suggests to examined this phenomena into heat transfer modelling.

The authors would like to thank the Ministry of Research, Technology, and Higher Education of the Republic of Indonesia to fund this research through Advanced Higher Education Applied Research Program (Program Desentralisasi Penelitian Terapan Unggulan Perguruan Tinggi) 2017.

\section{References}

1. Samtani, M.; Dollimore, D.; Alexander, K.S., 2002. Thermochim. Act. 393, (2002)

2. Subagjo, Wulandari, W., Fajrin, A., Aditama, P.M., AIP Conf. Proc. 1805, (2017)

3. Wulandari, W., Subagjo, Rio, A, Istiadi, P., Seminar Nasional Teknik Kimia Indonesia (2015) 